\title{
Fostering Africanisation: A Lesson of Identity Formation among Youth
}

\author{
Vuyisile Msila \\ College of Education, University of South Africa, PO Box 392, UNISA, 0003, South Africa \\ msilavt@unisa.ac.za
}

\section{Doi:10.5901/mjss.2014.v5n8p431}

\section{Abstract}

In recent years, africanisation of education has become a topical subject in most African countries, and South Africa is no exception. Conscientious Africans are looking at possibilities of africanising knowledge while keeping abreast with global trends. Some experts and philosophers have highlighted that making the curriculum relevant to the African context is very crucial and has a potential of enhancing learning among African learners. However, absent in many discussions are practical aspects as to how learners and their educators can play an active role in enacting africanisation of the curriculum in the learning sites. This study was conducted in the Eastern Cape Province in South Africa and the researcher employed transformational research strategies and participatory methods to investigate the potential effects of the introduction of African indigenous knowledge systems (AIKS) in a learning site. The study found that educators need to understand that democratisation of education calls for the acknowledgement that through education, learners can be assisted in making certain choices in life. The study also confirmed that part of the teachers' work is to assist the learners discover what they already have. Learners in Africa can, and should use the indigenous knowledge systems (IKS) to develop a sense of self, necessary for worthwhile living in their context. Furthermore, it was also established that transformational pedagogy would be crucial in the introduction of AlKS in the classroom.

Keywords: Africanisation, Indigenous Knowledge Systems (IKS), Personhood, Post-apartheid education

\section{Introduction and Problem Postulation}

Seepe (2004) contends that a radical restructuring of education in Africa which makes education relevant to African challenges cannot be complete without significant and serious consideration of the contribution of indigenous knowledge systems (IKS). This is an educational challenge to all Africans who aspire for the africanisation of knowledge. Furthermore, Seepe states that this educational challenge is not hard to understand considering that it is through education that values, cultural norms and the beliefs of a society are reproduced. There are a number of writers who have highlighted the relevance of IKS and African philosophy for teaching and learning purposes (Waghid, 2004; Wirendu, 2004; Msila, 2009). Waghid (2004) writes about the African philosophy's view of education: ....an African philosophy of education demonstrates the potential to promote justice, courage and truthfulness in individuals (that is, goods or excellences internal to achieving moral maturity and refinement). In other words, an African philosophy of education aims to contribute to the transformation of educational discourse in Africa; empowering communities to participate in their own educational development. The call for africanisation of the curriculum is a call to transform education to reflect the African ideals. Makgoba (1997) posits that africanisation of knowledge is about taking the African perspective to the centre. Viriri and Munwini (2010) also emphasise this definition when they point out that africanisation is a call to place the African worldview at the centre of analysis and recognition "that there are different pyramids for the construction of knowledge none of which should be regarded as inferior for knowledge is basically a cultural construct and hence boasts its own cultural regalia" (Viriri \& Munwini 2010: 30). An africanised curriculum enhances the search for African introspection; it comprises a search for an African identity. Furthermore, Kistner (2008) also argues that the debates for africanisation are ingrained in Afrocentrism; the veneration of all that is African.

Africanisation of education debate is beginning to move beyond mere sloganeering and romanticisation of "pristine" African cultures. Many social scientists and researchers are motioning for a move away from simplistic interpretations of the African philosophies, dubious explications and superficial applications of the processes of africanisation, African Renaissance and IKS as well as africanisation of the school curriculum. Africanisation of the curriculum is the realisation that innate African values need to be a sine qua non with democratic values endemic in African Renaissance. As nations embrace globalisation with boundaries gradually being blurred, nation states falling, Africa also needs to rise with its own unique identity. It is only through the realisation of this rebirth that Africa will be able to contest rationally and meaningfully 
with other nations of the global world. Gutto (2004) defines African Renaissance as that which is rooted in and born out of a painful history of struggle that is written in blood, sweat and tears spanning several epochs from the period of slavery up to the present phase of global imperialism. Furthermore, Gutto perceives African Renaissance as that which involves the struggle to invent African people and initiate fundamental changes in the governance of world affairs.

The introduction of the post-apartheid national curriculum in South African schools sees not only education that is rooted in the Constitution of the Republic but we also see a system that strives to give rise to a new learner and a new educator. The role of africanisation of the curriculum in South Africa needs to be seen in light of transforming the South African society by introducing elements of African philosophy that would assist in the transformation of knowledge production in schools; laying firm foundations for a democratic society. The Constitution of the Republic of South Africa (Act 108 of 1996) provides the basis for curriculum transformation and development (Department of Education, 2002). Furthermore, the DoE publication points out that the Preamble to the Constitution states that the aims of the Constitution are to:

- heal the divisions of the past and establish a society based on democratic values,

- social justice and fundamental human rights;

- improve the quality of life of all citizens and free the potential of each person;

- lay foundations for a democratic and open society in which government is based

- on the will of the people and every citizen is equally protected by law; and

- build a united and democratic South Africa able to take its rightful place as a sovereign state in the family of nations.

Looking at the above one will wonder whether the africanisation of the curriculum can enhance the realisation of the above aims. Africanisation of knowledge realises that there are a number of lessons that could be learnt from the indigenous cultures. It is also a realization that for many years Western scientists have misled people into believing that only the positivists' views can be accepted as rational knowledge and truth. This article explores a gap in research and seeks to investigate how the learners' psyche can be inspired to be receptive to IKS and its tenets. The study also wanted to explore how the africanisation of the curriculum can help in the transformation of learners. The main question asked is:

How can an africanised curriculum affect the cognitive faculties and personality of the learners?

Sub-questions addressed here are:

- How will communities benefit when the curriculum is africanised?

- In which ways will democracy be influenced by this system?

- What are the necessary strategies that can be utilised to empower educators dealing with indigenous knowledge systems in classroom?

\section{African Philosophy, IKS and African Renaissance: The Debates}

When debates about the africanisation of knowledge arise many critics overemphasise the need to define concepts. Without underscoring the definition of operational concepts, I shall also begin by exploring the concepts of African philosophy and indigenous knowledge. Odora Hoppers (2001) defines the concept indigenous as referring to the root of things; something natural to a particular culture. Bitzer and Menkveld (2004) define indigenous knowledge systems as the combination of knowledge systems encompassing technology, philosophy, social, economic, learning/educational, legal and governance systems. These are characterised by their propinquity in the culture and history of a people, including their civilisation. The call for the revival of recognition of IKS is much linked to the need to heed the call of African Renaissance. In his seminal work, Agendas, Alternatives and Public Policy, John W. Kingdon (1984) speaks of windows opening and closing during policy making; that when policy windows are opened it is crucial to put in them critical policies at that particular time. The past decade has been a fecund time in South Africa to introduce the African philosophy in the curriculum. This has been a time that is influenced by the need to see African Renaissance's surge. Van Wyk and Higgs (2004) argue that what is meant by an African Renaissance in educational discourse is founded on the perception that overall character of much educational theory and practice is overwhelmingly either European or Eurocentric. Furthermore, these writers aver that advocates of an African Renaissance in educational discourse have argued that much of what is taken for education in Africa is in fact not African, but rather a reflection of Europe in Africa. The IKS embedded in African philosophy and the spirit of African Renaissance is crucial for development and learning in African classrooms today. Bitzer and Menkveld (2004) cite Easton, Nikiema and Essama who reported an increased understanding of the various meanings and applications of indigenous knowledge in community development - they 
highlight three such areas of understanding; firstly, indigenous knowledge of communities should be conserved and respected, since it represents the accumulated (usually undocumented) wisdom of generations of people living and thriving in a particular community or context; secondly, indigenous knowledge embodies a different-and in their case a distinctly African-mode of thought that might be useful in view of the failure of most current methodologies of development; thirdly indigenous knowledge provides a means and process for the articulation of what local people know while involving them in the creation of the knowledge required for development.

When examining such critical arguments, one needs to see the function of IKS as vital in replacing the apartheid system of education. Seepe (2004:10) contends that africanisation and the promotion of IKS demands a re-examination of history, "the interrogation of cultural symbols and the re-configuration of models of intellectual emulation. This process cannot be achieved without critiquing, engaging and analysing values, assumptions, ideologies and interests embedded and reflected in the bodies of knowledge in institutions of learning". The curriculum needs to reflect positive references to Africa. In South Africa, apartheid education's mission was to produce docile and subservient blacks. In the famous quote of the then Minister of Native Affairs who later became a Prime Minister from 1958-1966, Verwoerd who stated:

My department's policy is that education should stand with both feet in the Reserves and have the roots in the spirit and being of Bantu society... There is no place for [the Bantu] in the European community above the level of certain forms of labor ... What is the use of teaching the Bantu child mathematics when it cannot use it in practice? That is quite absurd. Education must train people in accordance with their opportunities in life, according to the sphere in which they live. [Speech to Senate, June 1954] (Roux, 1972: 395)

The paradox of this statement is that Bantu education system for black Africans was from its inception, meant to alienate the black Africans from the European economy. However, the black Africans were already alienated from their own cultures. Bantu Education had been a means of restricting the development of the learner by distorting school knowledge to ensure control over the intellect of the learners and teachers, and propagating state propaganda (Kallaway, 1988). Among others, IKS and African inspired philosophy of education would yearn to address these and many other injustices in the education of the Africans. This system will have many challenges though: the society is still exposed to Western biased media or way of life, educators themselves were trained through Western curricula. The African children need to be strengthened in their context before they can compete globally. Seepe (2004:10) again argues:

This cannot be achieved without redressing the impact of imperialism and colonial exploitation. Accordingly, Africa's reawakening cannot and should not be restricted only to development, modernisation, and industrialisation of Africa, nor only to the elimination of mass poverty, and poverty-related diseases in Africa without addressing issues such as African culture, African civilisation and IKSs.

Education continues to affect societies and communities around the world. Automatically, education has an impact on the self of the teachers as well as their learners. We live in a world where we influence and in turn are influenced by our environment. However, socialisation plays a major role in shaping the attitudes that people have. Mutwa (1997:12) comments on the influence of education on how we think:

Western man (sic) is taught that he is that he is the master of all living things. The Bible itself enshrines this extreme attitude, as do other great books. Repeatedly one hears of Western people talking about nature as if it were man's mortal enemy: one hears dangerous phrases such as 'untamed nature' or 'interrogating nature with power.' She hears of the strange belief that man is superior to all other living things on Earth, and that he was especially created to be overlord and custodian of all things, animate or inanimate.

Education needs to challenge some or all the above attitudes. The learners need to understand other worldviews. The African viewpoints where people do not regard themselves superior to animals and nature in general need to be heeded. Curriculum that focuses on African cultures such as the relationships between the spirit world and the secular should be highlighted. The significance of legends and stories; the role and meaning of hunting; the role of gods are some of the many subjects that form part of what is learned in IKS. Learning more about these will make a significant impact on the self of each African learner.

\section{Theoretical Underpinnings}

Africanised curricula reflect "spatial here"- being in Africa, it reflects a system which utilises an African experience. The system reflects an experience of a certain location, which is Africa. Benson (2001:10) points out that location is the ontological condition for all human beings and that "not to be in a place is to be nowhere and to be nowhere is nothing". Furthermore, he states that location is sine qua non of human personhood. In analysing selfhood, Benson applies cultural psychology principles. Cultural psychology is fairly a new sub-discipline that has been gathering momentum since the 1990s. Cole (1996) sees cultural psychology as a field that stresses the content in which action happens. Everyday life is 
usually centered and developed in a particular context. Benson (2001) also points out that cultural psychology acknowledges the manner in which one is located in one's community, the manner in which that community is situated in a broader society and how that society stands in relation to other societies all have profound relevance for the kinds of mind and self that may be formed. It is also important to look at how these relationships are placed developmentally and currently in history.

Learners in classrooms come to school with some potential that already exists within. Part of the educator's job is to help the learners in finding out what is clearly in them (intrinsically). Hamachek (1995:31) states that:

\begin{abstract}
Another major implication growing from this point of view is the idea that in order to effectively teach students, we must try to understand them from their point of view. This is consistent with a little truism growing out of perceptual psychology: we tend to behave in terms of what we believe to be true - not what is true, but what we believe to be true about reality as we perceive it.
\end{abstract}

A good and effective teacher would help the learners to explore and understand personal meanings that are inherent in all of their experiences. Teachers who are humanistically inclined are concerned with the inner learner as they are with manipulating the external environment; they are as interested in their learners' current lives as they are in their histories (Hamachek, 1995). In a classroom, the teacher needs to give direction and guidance. The self is central in the humanistic perceptual view of human kind. The self emphasises the individual as each person sees him/herself underscores the role of consciousness in human behavior (Hamachek, 1995). Bugental (1965) suggested five basic assumptions for the humanistic-perceptual view:

a. Humans, as humans supersede the sum of their parts

b. Humans have their being in a human control

c. Humans are aware

d. Humans have choice

e. Humans are intentional

All the above convey the idea of who a person is. People become who they are due to the choices that they make.

\title{
4. The Study
}

\subsection{Research Methods}

Convenience sampling was used to select 20 participants from arts and culture groups in the Eastern Cape Province, the Southern part of South Africa. According to Struwig and Stead (2004) point out that convenience sampling is chosen purely on the basis of availability; that participants are selected because they are accessible and articulate. This was appropriate here because all the participants were somewhat homogeneous, black African youth who were members from five cultural groups whose focus was traditional dancing, traditional music and some drama. Their ages ranged from 15 to 20 and nine of them were female. All these groups were located relatively close to the researcher. In this study transformational research techniques were employed. There was much dialogue with the participants. Schwerin (1998:92) states:

Teaching and dialogue with students can provide insights and pose provocative questions that may stimulate research projects. The classroom can serve as a laboratory for designing and testing new experiments in teaching. Students from the same class or another class may benefit from helping to develop the research design, collect the data, perform the analysis, and collaborate with the teacher in writing up the results.

I used a number of tools usually employed by transformational scholars. Transformational scholars see a synergistic relationship between what is researched and how it is researched (Schwerin, 1998). For example in investigating aspects of democracy in indigenous knowledge systems I employed participatory action research based on collaborative teamwork. When the participants were looking at the interconnectedness between nature and human beings, they spent time in nature reserve to appreciate the symbiotic dependence in the ecological web. As Schwerin (1998:92) puts it, "from transformational perspective, research and teaching, process and content, enrich and enhance each other".

The study was more interested in the investigation of whether or not africanisation of the curriculum would have a positive impact on the cognitive development of the learners. I was also interested into exploring whether africanisation of education has any potential of addressing several aspects such as nation-building. Transformational researchers are 
interested in a variety of topics and phenomena and these might include peace movements, democratic movements and environmental politics (Schwerin, 1998). Schwerin also states that there are four main themes where transformational researchers draw theoretical insights:

- Theme 1: Emergence of a new paradigm. Obsolescence of the prevailing paradigm. The emerging paradigm draws from many sources.

- Theme 2: Ecological focus. This emphasises the importance of understanding the interdependence of all members of an ecological community, such as the importance of diversity in complex communities.

- Theme 3: The linkage of personal and political transformational research looks at how we live our lives in a broader sense; at home, in the workplace and in the natural world.

- Theme 4: The inclusion of the spiritual and sacred. Here there is the importance of focusing on aspects of personal transformation which include the personal, political, historical and sacred.

This study combined all the themes illustrated above. As I delved into the investigation, I also developed a theory of empowering the participants as we informed both personal and political transformation; the latter is an important goal of transformational research. The study also focused on possible theories as to how to equip participants to be receptive and critical towards indigenous knowledge systems. At the initial stages, the study yearned to see personal empowerment of the participants. I wanted to see the possibilities of an action research that would lead to "critically conscious" participants. I also used a number of conventional and unconventional methods. I interviewed participants, made use of storytelling including traditional myths, legends to interpret the meaning of indigenous knowledge systems. The participants were also engaged in a number of activities to see how they perceived issues such as indigenous languages. Basically, action research (which was also employed) is a strategy, which brings about social change through action, developing and improving practice and at the same time generating and testing theory (Brink, 2000). Action research is a way of conducting research and solving the problem at the same time. While I was looking at theory of IKSs, I was also trying out a few strategies as to how educators can instill an IKS inspired curriculum in their broad learning or cultural sites. Brink also cites Bless and Higson-Smith who point out that action research can be a particularly valuable tool in developing countries because:

a. it is concerned with solving the particular problems facing communities;

b. it helps individuals, organisations and communities to learn skills and get resources so that they can function more effectively in future;

c. it provides a way of spreading the understanding gained through research to people and communities who can benefit from those findings;

d. it attempts to understand the person and the community within the broader social context;

e. it aids communication between social researchers and communities in need of assistance;

f. it takes the ivory tower of many social scientists and makes their work directly beneficial to society.

\subsection{The findings}

The sample used in the study was very useful in collecting rich data necessary in qualitative studies. The various methods employed in exploring the effects of indigenous knowledge systems learning among young people were effective in revealing a number of aspects relevant to the study. The research exposed much relevant data about the participants who were actively involved in all the stages of the study. The research witnessed their evolution from being ignorant about the indigenous aspects of culture to being more accommodating and understanding. In the four months in which I was in contact with the participants, I learnt various aspects when looking at westernisation and africanisation. Many of the participants were skeptical about the indigenous knowledge systems initially. All of them born in the urban areas perceived the urban lifestyle as the only appropriate lifestyle. To them indigenous cultures reflected backwardness and "being old fashioned". One participant stated:

We try in many of our groups to portray some of the indigenous culture. But some of us always wonder at the back of our minds whether this is the way to go. Our world has changed immensely and old traditional cultures might not be the way to go.

Another concurred when she pointed out:

These themes are always important for example, I would ask myself whether we really have any chance of succeeding in the society if we go traditional. I am for Africa all the time, but I am confused as to whether the adoption of indigenous 
knowledge systems would not stall our progress as young people.

Some youth though maintained that the IKS inspired education was a best alternative although they did not always know where to get it. Siya stated:

\begin{abstract}
When I see these pictures, old traditional pictures- I always wish we could go back there; life in the rural areas where nature was close to man. Westernisation has killed all that. However, many of us young people are not certain as to how they can balance traditional culture and modernisation. It can be very difficult to find this balance and as such that is why many would always ask, do we want to go back there?
\end{abstract}

It was apparent during the gathering of data that indigenisation of knowledge among people would not be easy without the raising of cultural awareness. The youth is growing up in a Western culture whose media promote values that are not necessarily African in origin. For example participants agreed that many young people "know the American culture more than the African indigenous cultures". They continued to explain that the youth is not to blame because this is what they are exposed to in the society. Many also averred that they decided to join these cultural clubs because they wanted to see the semblance of "black culture". They wanted "to learn about the beauty in antiquity". Many argued though it is "frequently tough" because everything in their eyes was "very Western".

When the group paid a visit to a nature reserve there were discussions around the need to kill animals. They were looking at a lion's carcass when discussions around the African and hunting arose. Many concurred that in the past hunting was done when it was necessary. Some showed others how each creature depended on the next for survival and how the current generation tends to randomly destroy nature. The participants were very critical of the manner in which nature was being destroyed. The study occurred when the debates were rife on the killing of the rhinoceros animals for their horns. They discussed the senseless killing of these animals by poachers. During the duration of the study the participants learnt more about themselves as well as their peers. The new concepts of indigenous knowledge systems opened the participants' minds and they were able to criticise various aspects of life in their own society. The new knowledge reshaped their thinking and outlook of life. Even the participants who were quiet and more inward looking at the beginning of the study they became more engaged in the dialogue happening in the sites of the research. It was important for the participants to learn about the opportunities and challenges of living in a multicultural society. During the course of the study the participants learnt and understood concepts such as ethnocentrism, acculturation and assimilation. These terms and a number of others made them understand why some cultures are lagging besides others. It was important for them to understand the importance of each culture in society. It was also interesting to note how the participants re-examined their views on cultures. At the beginning of the study they were shown several pictures from all over the world. It seemed that they identified with "Western" pictures depicting rap stars or other "ordinary people".

However, they laughed uproariously on seeing pictures of semi naked San and Khoi hunting. They also ridiculed the pictures showing various groups of ethnic group performing rites of passage. It seemed that the indigenous communities depicted some unique queer cultures. The participants also saw that there are many answers that their own schools can get from the community. They saw the value of using elders' wisdom; the telling of stories, folklore, culture and values of different ethnic groups in South Africa. The participants said it themselves that schools should use more contact between themselves and the surrounding communities. Many said no parent or elder of the community had ever been invited into their own classrooms at their schools. They found it exciting to ask questions about various issues that affect their communities. After stories and songs they asked questions that pertained to AIDS, relationships and similar topics. One other aspect that was enriching about the study was that the participants were able to see indigenous culture as being applicable to their formal school curriculum. They made several examples of how indigenous knowledge can help at school. For example, they perceived certain indigenous games as being helpful in assisting learners in numeracy because the players needed to count. The various traditional songs and stories are some of the aspects that taught the participants that there are a number of aspects that can be applied to mainstream formal education from traditional cultures; many of these songs carried didactic messages from the past. Generally, the multi-pronged interdisciplinary approach to learning indigenous knowledge systems for the participants led to the "opening of their eyes". Most of them contended that they had never thought that there are so many interesting aspects about the traditional culture. The majority of the participants stated that before being involved in this study, they only knew the "urban culture" which they thought was "cool". 


\section{Discussion of the Findings}

\subsection{Liberatory teaching, democracy and indigenous knowledge systems (IKS)}

The researcher in the study tried to instill the adoption of cultural pluralism to support the various South African cultures in formal education settings. Basing teaching on tolerance, democratic ideals and the Constitution of South Africa is the cornerstone of the post apartheid education system. In fact, this system seeks to promote equity and multiculturalism where education does not prejudice against any group in the society. Through this study we saw that participants could unlearn some of the lessons learnt from contact with the dominant culture. The participants were exposed to a climate of cultural tolerance where every culture was accorded the respect it deserved. Activities such as role-play, extracts from films, books, and pictures were used to show the different cultures among the participants. As the participants started to discuss various topics on culture, they began realising that all cultures are important. The participants were also taught to be critical of a number of texts that were used in the past that usually portrayed the traditional culture as backward and repugnant. Many of the school texts used in the past tended to bear ethnocentric views. However, through critical pedagogy the participants learnt that education is a dialogic encounter where they can be able to question any aspects in their education. The researchers also realised that prejudices and stereotypes learnt in the society can be discarded through conscientious and meticulous facilitation in the classroom. In fact, for schools to prepare their learners for an africanised system of education and a multicultural society based on democratic values, they need to sensitise educators to build a new identity. This new identity will be based on values of cultural tolerance and equity.

\subsection{Schools and local cultures: manifesting democracy}

Classrooms should not be seen as entities that are divorced from the society they are situated in. Participants in the study applied much knowledge from discussion sessions on indigenous knowledge systems. As they started understanding the basics of indigenous knowledge systems they were able to challenge the stereotypes existent in the society. The latter showed the role that schools could play in bringing about social transformation and democracy. The schools have a role of either enhancing or challenging socialisation into inequality. The school is a dependant sector of society that can reproduce alienated consciousness. It is also an arena of contention where critical educators can challenge inequality through a critical curriculum in a democratic learning process (Shor, 1987). The post-apartheid education system in South Africa yearns to introduce egalitarian pedagogy schools. The goals of this system are to create a new South African identity that encompasses critical consciousness, transformation of the South African society, promote democracy and magnifying learner involvement in education. Learners and teachers need to be exposed to a system that embraces democracy to build this egalitarian society.

Education is the key because it empowers citizens to exercise their democratic rights and shape their destiny (DoE 2001). Democratic education also enables people to participate in public life, think critically and act in a responsible manner. Democracy and education as a subject of discussion has not been without problematic areas. Chubb and Moe (1990) state that there are no panaceas in social policy. This is supported by Plank and Boyd (1994) who point out that democratic governance is not a panacea for the problems of educational system. However, Gutman (1999) posits that the professional responsibility of teachers is to uphold the principle of no repression by cultivating the capacity for democratic deliberation. South Africa is a multicultural country and education needs to reflect this multiculturalism. Currently, there is a move by the post apartheid education system to meaningfully include indigenous knowledge system in schools. As apparent in the study, many participants had lost their cultural identity, even those who had parents "who practice some of the traditional practices". The fact that many schools are not fostering indigenous cultures send a message to the learners that traditional culture is not important. There are so many fallacies that play against the traditional cultures. Many learners (as shown in the study) tend to believe that African cultures are references to "black magic", "superstition" and "ungodliness". The learners seem to learn it from the dominant society and they tend to internalise these stereotypes.

Bude (1985) pointed out that African culture is interrelated with religious beliefs, moral values and social modes of behavior. The storytellers who came to the group showed this affinity in their stories and explication of the indigenous arts and cultures. The stories narrated as well as the riddles, idioms and songs all reflected the interrelationship between religions, beliefs and morality. After being told the various stories the participants' saw the didactic value of songs, stories and riddles. Within the narration they could see the interconnectedness of human beings and their environment. Schools can learn much from this. Bude (1985) points out that schools can either contribute towards the enhancement of the cultural environment by endorsing their values for the socialisation process. Furthermore, he states that if the schools negate these values, they will help in the acceleration of the loss of identity on the part of the learner. When the 
participants understood the historical and cultural stories, they began to realise the importance of understanding the culture of the people in their communities. Another aspect that schools need to take cognisance of is the issue of accommodating the indigenous languages in the classroom.

\subsection{The language of the curriculum}

In South African township schools many able parents are exercising the choice option by moving their children away from the historically black schools to historically white schools. Reasons cited by parents vary from the pedagogically sound to the pedagogically absurd. Some parents who exercise this choice are not informed when making their decisions to send their children to city or historically white schools. The majority want their children to speak better English (Msila, 2005). Many parents are opposing mother tongue teaching because they perceive English medium education as a ticket to the successful world of work. The parents whose children remain in the township schools continue to put pressure on schools to ensure that their children can and will speak better English. In this study the participants displayed how language can alienate people from their own culture. The realisation of the recognition of indigenous knowledge systems would be incomplete if indigenous languages continue to be marginalised. There were a number of times when the participants were encouraged to converse in their own mother tongue. Initially, this created some problems, especially for the few that attended the ex Model C schools (former white schools) where the English language is emphasised. Many participants found it challenging to express themselves in their mother tongue. Initially, the majority of them would laugh before uttering a word in their indigenous language, and in this case the common indigenous language was IsiXhosa. This is after they were asked to converse purely in their mother tongue.

It was however, later in the study that the participants attempted to speak their indigenous language well. They found out that it was in fact, much easier to express oneself in their first language. The idea of language in black education was what Biko writes about in his work (Biko, 1978). Biko was concerned about the way the use of English (as a second language) was emphasised in educational institutions. Language created black African people who had an inferiority complex. Biko also writes about how black Africans became less articulate, more inward-looking as a result of the lack of linguistic skills. In a foreign language, "you feel things rather than say them... English is completely foreign and therefore people find it difficult to move beyond a certain point in their comprehension of the language" (Biko 1978: 123). Towards the end of the study most of the learners were proud in using their own languages and this also had an impact upon their confidence. Bude (1985) states that the development of the learners' cognitive abilities through a foreign language must necessarily result in cultural alienation. A number of black African learners in South African schools are alienated from their cultures as a result of school choice. The black African elite bus their children to private schools and historically white schools where indigenous languages are not a priority. The learners grow up in these schools not being able to express themselves adequately in their mother tongue. The acquisition of English by these learners has a number of consequences. Those who excel in it are seen as intelligent and prone to success. Secondly, as Bude states, instruction in non-African language will not only widen the gap between literate children and illiterate parents but conveys to the learners via the language a pattern of thought and experience which deviates from that of their parents.

One understands the concerns about the large number of African languages in South Africa. Some would argue for example that English serves as a language to foster unity and nation building in a multicultural society. However, as nonnative speakers of English use less of their own languages, they gradually become alienated from their own culture. The participants in the study were not able know what certain words meant in their own languages. The changed perception that the participants assumed towards their language altered them cognitively. The learners began to understand that their culture is contained in their language. This means that teachers will have a crucial role to play in teaching the learners; they need to understand the backgrounds of their learners. Delpit (1995:44) states that if teachers know the intellectual legacies of their learners, they will gain insight in how to teach them. Featherstone $(1995: 221)$ concurs by pointing out that a teacher's job is to build bridges between the broad culture of the school and the local neighborhood cultures of the learners.

\subsection{Meaningful community involvement}

A number of studies have shown the invaluable contribution that can be made through community participation in education (McDonough \& Wheeler, 1998; Rugh \& Bossert, 1998; Bude, 1985). The parents and the community are not a homogeneous group though. Ordinarily, many do not have any direct impact on the development of the curriculum. However, there is much that can be learnt from the diverse population of parents and communities. The participants learnt an array of skills, ideas and practices from various parents who came to share various aspects of culture. The 
unpacking of some aspects of culture by community members is valuable in enhancing the learning process. Community involvement in education ensures that schools do not operate in isolation. The latter also enabled the participants to appreciate the relevance of the community involvement in education.

Parental involvement in education has a potential to change the perceptions of learners towards their formal education. The introduction of african-centered, indigenous knowledge systems will need the maximum involvement of the parents and community. The community members have a broad spectrum of experiences that the schools can learn from. Communities are a source of a number of educationally enriching aspects and this includes oral traditions. Emeagwali (2003:4) points out that the most significant information gathering exercise for African indigenous knowledge systems is oral tradition. These include the collective testimonies and their recollections of the past inherited from earlier generations and passed on in various forms of verbal testimonies. Emeagwali also cites Vansina's five categories of oral tradition, which continue to be relevant even today. Vansina's stated that oral tradition is embedded in slogans, spiritually derived language, poetry, and leadership, lists of reigning monarchs, narratives and commentaries. Some of these were manifest in the above study.

\section{Conclusions and Recommendations}

This study showed how learners can be positively affected by africanised curricula. It enables them to understand the African environment they inhabit. The community also becomes relevant under this system, for it can benefit formal education which in turn will enrich it. The study showed that successful indigenisation of knowledge in African classrooms needs a paradigm shift. On the one hand, teachers need some form of reeducation as they confront the entrenched belief systems biased towards "Western approaches"; whilst on the other the participants in the study had to undergo some form of psychological change for them to perceive opportunities of an african-centered curriculum. The African cultures are rich and complex; learners can learn to see the world from a different and fresh perspective. Using the cultural frame of reference also enables one to appreciate diversity, and this is the basis of democracy. African teachers need to be prepared for this scenario for them to be able to enrich their learners' lives. Furthermore, the study illustrated that for educational transformation to be effective and the adoption of a valuable paradigm shift, teachers need to be not only implementers but also to be formulators of an envisaged curriculum. African-centered curriculum aspires a pedagogy based on creating "a complete" African citizen. Teachers need to facilitate a pedagogy that promotes democratic concepts of peace, social justice and various other important crucial concepts embraced by an africanised system of education and way of life. Nguru (1995) maintains that integration; adequate preparations of pre-service and in-service teachers, alternative instrumental strategies, dialogue, flexible classroom climate to foster participatory skills, utilising adequate instructional resources and assessing of learner knowledge are aspects that need to be addressed by a curriculum that addresses democratic citizenship. Whist it should be stressed that democracy is not unique to Africa only as Western literature also supports the ideals of this philosophy. However, the African-centered philosophies underscore the democratic values enshrined in ubuntu or African humanism which is regarded as crucial for survival in African societies. Ubuntu is based on the age old maxim which declares, "I am because you are". Teacher education programmes have to explore the transformational approaches to enhance self-esteem of both themselves as well as their learners. As Schwerin (1999:108) puts it:

Transformational approaches should be designed to enhance self-esteem and self-efficacy, to develop the knowledge, skills and political awareness essential for democratic citizenship, to teach students and encourage them to take responsibility for their communities and their world. A guiding question or compass for transformational teachers might be; what can I do to make my approach to teaching more empowering?

Based on this study there are a few recommendations that were drawn. How do we prepare learners for an africanised system of education? The following were the recommendations drawn:

- Teachers should make their facilitation of learning more learner-centered. Emeagwali (2005) points out that learner-centered learning is crucial in pursuing programmes on indigenous knowledge systems to ensure assimilation of information and to create possibilities for meaningful research.

- Community involvement in education is crucial in creating education that is relevant and has a bearing on the learners' lives

- Teachers should make use of oral traditions at all times in their classrooms. The education system can glean much from the unwritten knowledge systems from Africa. 
- Schools need to include IKS in their curricula because much of this knowledge has deep implications for nation building, intellectual development of Africans in the present century.

\section{References}

Benson, C. (2001). The cultural psychology of self: Place, morality, and art in human worlds. New York: Routledge.

Biko, S. (1978). I write what I like. London: Penguin.

Bitzer, E., \& Menkveld, H. (2004). Drawing on indigenous knowledge: Students' learning in and from a rural community. South African Journal of Higher Education, 18 (3), 226-240.

Bude, U. (1985). Primary schools, local community and development in Africa. Baden-Baden: Nomos Verlagsgesellschaft.

Bugental, J.F.T. (1965). Challenges of Humanistic Psychology. New York: McGraw Hill.

Chubb, J., \& Moe, T. (1990). Politics, Markets and America's Schools. Washington,

Delpit, L. (1995). I just want to be myself: Discovering what students bring to school in their blood. In W. Ayers. (Ed.), To become a teacher: making a difference in children's lives (pp.34-48). New York: Teachers College.

Department of Education. (2002). Arts and culture-Revised National Curriculum Statement grades R-9. Pretoria: Government Printer.

Emeagwali, G. (2005). African Indigenous Knowledge Systems (AIK): Implications for the Curriculum. [Online] Available: from www.multiworld.org/m_versity/articles/gloria. January, 8, 2014.

Featherstone, J. (1995). Getting a life: A new teacher's guide. In W. Ayers. (Ed.), To become a teacher: making a difference in children's lives (pp.221-230). New York: Teachers College.

Gutman, A. (1999). Democratic Education. Princeton: Princeton University Press.

Gutto, S. (2001). The reform and renewal of the African regional human and peoples' rights system. African Human Rights Law Journal, 175-184.

Hamachek, D.E. (1995). Psychology in Teaching, Learning and Growth. Boston: Allyn and Bacon.

Kallaway, P. (1988). From Bantu Education to Peoples' Education. Cape Town: UCT.

Kingdon. J.W. (1984). Agendas, Alternatives and Public Policies. Boston: Little Brown and Co.

Kistner, K. (2008). "Africanisation in tuition: African national Education?" Mediations, 24 (1), 90.

Makgoba, M.W. (1997). Mokoko: The Makgoba affair - a reflection on transformation. Florida: Vivlia.

McDonough, M.H., \& Wheeler, C.W. (1998). Toward school and community collaboration in social forestry: lessons from Thai experience. Washington: USAID.

Msila, V. (2009). Africanisation of education and the search for relevance and context. Education Research and Reviews, (June), 310315.

Msila, V. (2005). Education Exodus: The flight from township schools. Africa Education Review. 2(2), 173-188.

Nguru, G.M. (1995). Education and democracy. In South African Journal of Education, 15, 59- 62.

Odora Hoppers, C.A. (2001). Indigenous Knowledge Systems and Academic Institutions in South Africa. Perspectives in Education, 19 (1), 73-85.

Roux, E. (1972). Time longer than rope. Wisconsin: University of Wisconsin Press.

Rugh, A., Bossert, H. (1998). Involving communities: participation in the delivery of educational programs. Washington: USAID.

Schwerin, E. (1998). Transformational research and teaching. In S. Woolpert., C.D. Slaton., \& E.W. Schwerin (Eds.), Transformational politics (91-118). Albany: State University of New York Press.

Seepe, S. (2004). Editorial. South African Journal of Higher Education, 18 (3), 9-16.

Shor, I. (1987). Educating the educators: A Freirean approach to the crisis in teacher education. In I. Shor. (Ed.), Freire for the classroom (pp.7-32). Portsmouth: Heinemann.

Struwig, F.W., \& Stead, G.B. (2004). Planning, designing and reporting research. Cape Town: Pearson Education.

Van Heerden E (1997). Cultural diversity and schooling. In E.M. Lemmer., \& D.C. Badenhorst. (Eds). Introduction to education for South African teachers (187-214). Kenwyn: Juta.

Van Wyk, B., \& Higgs, P. 2004. Towards an African philosophy of higher education. South African Journal of Higher Education, 18 (3), 196-210.

Viriri, A., \& Mungwini, P. (2010). African cosmology and the duality of Western hegemony: The search for an African identity. The Journal of Pan African Studies, 3(6), 27-42.

Waghid, Y. (2004). African philosophy of education: Implications for teaching and learning. South African Journal of Higher Education, 18 (3), 56-64.

Wiredu, K. (2004). Editorial-Prolegomena to an African philosophy of Education. South African Journal of Higher Education, 18 (3), 1726. 